\title{
Physicochemical and Bacteriological Analyses of Well Water in Abeokuta Metropolis, Ogun -State, Nigeria
}

\author{
Taiwo, A.A ${ }^{1}$; T.O Ijaola ${ }^{1}$; O.Jiboku ${ }^{2}$;. Oluwadare ${ }^{3}$ and A. Osunkiyesi ${ }^{1}$ \\ ${ }^{I}$ Chemistry unit, Department of Science Laboratory Technology, Moshood Abiola Polytechnic Abeokuta, Ogun \\ state, Nigeria \\ ${ }^{2}$ Biology/Microbiology unit, Department of Science Laboratory Technology, Moshood Abiola Polytechnic \\ Abeokuta, Ogun state, Nigeria \\ ${ }^{3}$ Institute of Public Analyst of Nigeria
}

\begin{abstract}
Physico-chemical and Microbial analyses were carried out on fifteen well waters in Abeokuta. The ranges of the result obtained are temperature $\left(27.1^{\circ} \mathrm{C}-27.6^{\circ} \mathrm{C}\right)$; colour (5-10HU); Turbidity $(1.05-6.78 \mathrm{NTU})$ ;pH (5.19-7.47).The odour was unobjectionable for samples 1,2,3, 11,12,13,14,and 15, others were objectionable. Sample 3 had the highest observed value for acidity $(1.00 \mathrm{mg} / \mathrm{l})$. The values observed for total hardness and chloride ranged between 39-137mg/land 44-298mg/l respectively. All the samples had no alkalinity, iron and chloride residues, traces of Nitrite was observed. The total viable counts for all the water samples exceeded the standard limit of $1.0 \times 10^{5} \mathrm{cfu} / \mathrm{ml}$, the presumptive coliform counts, ranged between 10 $x 105 \mathrm{cfu} / \mathrm{ml}$ and $60 \times 105 \mathrm{cfu} / \mathrm{ml}$, the total coliform count also ranged from 10 to $20 \times 10^{5} \mathrm{cfu} / \mathrm{ml}$. All the water sample showed high concentration of Escharichia coli,this exceed the standard limit of zero ${ }^{14}$.The isolated identified were, Escharichia coli, Pseudomonas spieces, Bacillus subtilis, Klebsiella species and Entrobacter species. The observations indicate that the water in these wells are not fit for consumption except they are properly treated and screened.
\end{abstract}

Key words: Bacteriological analysis, physicochemical, water pollution, water quality, well waters.

\section{Introduction}

Water is essential to all life both animals and plants. It is capable of dissolving an enormous range of subtances making it ideal medium for life, both invitro and vitro cell ${ }^{1}$. Most people in the world have no access to save drinking water and this has led to increase in water borne diseases which kill more than six million children every year ${ }^{2}$. Water quality assessment has become a big issue today because of the potential hazards associated with the use of contaminated water supply. Various researchers have reported on the serious and severe illness like typhiod fever, Cholera, dysentry resulting from the use of contaminated water supply .Also water of poor physico-chemical quality may have adverse health effect causing unavoidable economic and human losses ${ }^{3}$.

Scarcity of portable water is pronounced in Abeokuta, all the effort of the government to provide portable water to the citizens prove abortive because the government cannot afford the cost of infrastucture outlay needed to provide portable water for a population of more than 1 million people. So, the people have to resort to digging shallow wells which is cheaper than a deep well or a bore hole to meet their immediate domestic needs. Therefore, adequate attention needs to be giving to this source of water. It becomes imperative that the water meant for human consumption should be free of diseases causing germs and toxic chemicals that pose a treat to public health.Hence the objective of this research is to determine the quality of some well water in different locations in Abeokuta.

\subsection{Sample Collection}

\section{Material And Methods}

Samples were collected from four local government areas in Abeokuta metropolis. They were obafemi Owode, Abeokuta South, Abeokuta North and Odeda Local Governments Plastic sample containers(1.5Lt) were washed with detergent, rinsed with water and sterilized. The bottles were properly labelled, the samples were kept in the refrigerator prior to the analysis

\subsection{Chemical Analysis}

The temperature of the $\mathrm{H}_{2} \mathrm{O}$ samples was determined by using a thermometer. The odour and taste were done using the sensory analysis according to the hedonic scale . $\mathrm{pH}$ was determined using the $\mathrm{pH}$ metre (Jenway model) which was used after it was calibrated with standard buffers $4.0,7,9,14^{4}$. Nessler tube was used for colour determination 10mls of sample water was put in the Nessler tube, this was compared with the ionization 
comparator disc, and the result was taken directly from the disc ${ }^{4}$. The odour was determined with sensory analysis method. Total suspended solid and total dissolved solid were estimated by gravimetric method described by Trivedi ${ }^{5}$. EDTA titration method was used to determined the total hardness, calcium and magnesium hardness of the water sample.Chloride was determined by adding ten mililitres of potasium dichromate $\left(\mathrm{K}_{2} \mathrm{Cr}_{2} \mathrm{O}_{7}\right)$ into $100 \mathrm{ml}$ of water sample and titrated against silver nitrate $\left(\mathrm{AgNO}_{3}\right)$, a faint brick red colour marked the end point ${ }^{6}$. Iron and chlorine residue were determined using lovibond tube ${ }^{7}$.

\subsection{Microbiological Analysis}

Presumptive coliform count was done as described by Arova and $\operatorname{Arova}^{8}$, measured amount of water sample was added by sterile graduated pipettes as $50 \mathrm{ml}, 10 \mathrm{ml}, 1 \mathrm{ml}, 0.1 \mathrm{ml}$ volumes of water samples were added into $50 \mathrm{ml}, 10 \mathrm{ml}$ double strength medium and $5 \mathrm{ml}$ single strength in the inoculated bottles. These were incubated at $37^{\circ} \mathrm{C}$ for 48 hours, the presumptive coliform count per $100 \mathrm{ml}$ was determined from the bottles showing acid and gas using the probability table. After the presumptive test, Confirmed E.coli count was determined by preparing some subcultures from all the bottles. The media used were Mancconkey broth and Macconkey agar with sterile peptone water,the sub-cultures were incubated at $37^{\circ} \mathrm{C}$ and $44^{\circ} \mathrm{C}$ and examined after 24hours. Total plate count was done by pipetting $1 \mathrm{ml}$ of each water samples into four sterile dishes and $1 \mathrm{ml}$ of water to $9 \mathrm{ml}$ of diluents in sterile test tubes, then $1 \mathrm{ml}$ of $1 / 10$ dilution was added to each of the four petri dishes and $9 \mathrm{ml}$ diluents, also 1/100 dilution was added to two petri dishes followed by $20 \mathrm{ml}$ of molten yeast extract agar, these were mixed gently in a clockwise and anti- clockwise directions.Two of the plates inoculated with undiluted sample, while the other two were inoculated with $1 / 10$ dilution and these were incubated at $37^{\circ} \mathrm{C}$ for about 24hours, the remaining plates having $1 / 10$ dilution were incubated at $22^{\circ} \mathrm{C}$ for 72 hours ${ }^{9}$. The isolates were identified by morphological methods viz; colonial morphological gram staining and motility,indole,citrate,Urase,Methyl red voges prosker (vp)hydrogen Sulphite and sugar fermentation test ${ }^{8}$

\section{Results And Discussion}

Table 1 presents the physical parameters of water samples. The result showed that the temperature ranged between $27.1-27.6^{\circ} \mathrm{C}$, the value obtained were lower than values obtained by Amoo and Akinbode ${ }^{10}$ for well water in Minna $\left(30.0^{\circ}-32.5^{\circ} \mathrm{C}\right)$ and Mulusky, $(1974)$, they observed a range of $28-30^{\circ} \mathrm{C}$, the water body is believed to have been influenced by the intensity of sunlight. The result is slightly different from the observation of Shamaya et al., (2008) who reported temperature range of $26.3-27.2^{\circ} \mathrm{C}$, they attributed this to early summer months which prevailed during the period of investigation.also the values observed fall within the $26-30^{\circ} \mathrm{C}$ reported by Albster and Lloyd (1980) for surface water, they attributed it to the insulating effect of increased nutrient discharge into the water bodies from the industries. Temperature is an important parameter for aquatic enviroment, it is governed by physical, chemical and biochemical properties. The values observed for colour were above the maximum allowed by NAFDAC and SON(3.0 and 2.0 TCU respectively) but within the maximum permisible level for $\mathrm{WHO}(15 \mathrm{TCU})$. Colour and particles in water are due to the presence of organic matter associated with the humus fraction of the Soil ${ }^{11}$.

Sample 5 has odour, this may result from contamination with dusty particle sand dissolved solids ${ }^{12}$, all other samples were odourless, this observation is similar to the report of Daniel et $a l^{13}$. Obantoko well had the least value for turbidity (1.05NTU) while the highest value was observed in Adigbe well (6.70NTU),turbidity is used to indicate water and filtration effectiveness, higher turbidity levels are often associated with higher levels of disease- causing micro-organisms such as Viruses, Parasites and some bacteria which can cause symptoms such as nausea, cramps, diarrhea and associated headaches ${ }^{14}$. The value of total solid, total suspended solid and total dissolved solid ranged between ; $180.00-883.30,162.70-575.00 ; 122.5-614.00 \mathrm{mg} / \mathrm{l}$ respectively,the values of total solid obtained for sample $3,5,6,7,8,9$, and 10 were above WHO and SON standards, $500 \mathrm{gm} / \mathrm{L}^{[15,16]}$. These high values may be due to ground water pollution by waste waters which may originate naturally or introduced through human activities ${ }^{11}$. The results of Onuh and Isaac ${ }^{17}, 4.6-39.20 \mathrm{mgl}$; Amao Kehinde et $\mathrm{al}^{18} 2.0-36 \mathrm{mg} / \mathrm{l}$, were lower than values observed.

Dissolved solid's content for the samples were below $600 \mathrm{mg} / \mathrm{l}$ permisible level recommended by WHO and SON ${ }^{[15,16]}$, except sample $10(614 \mathrm{mg} / \mathrm{l})$ and $11(657.00 \mathrm{mg} / \mathrm{l})$. The chemical parameters are shown in table 2 , the conductivity values ranged between 73.10 and $46.7 \mu \mathrm{s} / \mathrm{cm}$, values obtained for samples $6,10,11$, and 12 were above the recommended value of $\operatorname{NAFDAC}(1000 \mu \mathrm{s} / \mathrm{cm}), \operatorname{SON}(1000 \mu \mathrm{s} / \mathrm{cm})$ and $\mathrm{WHO}(900 \mu \mathrm{s} / \mathrm{cm})$. This measures the ability of the water to conduct electricity which depends on the concentration of dissolved substances and temperature. The desirable limit of alkalinity in portable water is $120 \mathrm{mg} / 1^{19}$, the maximum permissible level is $600 \mathrm{mg} / \mathrm{L}$, no alkalinity was observed in all the samples

The Nitrate contents observed for all samples were above the standards of SON, NAFDAC and WHO, samples 3,4,7,11, and 12 have Nitrate content which were a bit higher than the recommended value $0.02 \mathrm{mg} / \mathrm{l}$. The values observed for Sulphate are high in all samples compared to the recommended(100mg/l).All the water samples had traces of nitrite $(0.02-0.21 \mathrm{mg} / \mathrm{l})$. WHO required that Nitrite should be negligible because it forms 
$\mathrm{N}$-nitroso compounds with Nitrogen in human stomach and accumulation of these act as potent carcinogens ${ }^{11}$, Nitrite also has the ability to cause infant Methaemoglobin anaemia or blue baby syndrome ${ }^{20}$. Calcium content is present in almost all the samples except samples 6 and 9,Magnessium content range between (2.00$68.00 \mathrm{mg} / \mathrm{l})$, eight samples fall within the standard $(20 \mathrm{mg} / \mathrm{l})$. The lead content are above the recommended value in all samples, the Chromium content is below detection limit. The result of the microbial analysis of the water samples are shown in Table 4, the presumptive total coliform count of the water samples ranged from $10 \times 10^{5}-$ $60 \times 10^{5} \mathrm{cfu} / \mathrm{ml}$, it indicates that water from Randa had the highest coliform count of $60 \times 10^{5} \mathrm{cfu} / \mathrm{ml}$ followed by Oluwo,Obantoko.Ijaiye and Camp $\left(40 \times 10^{5} \mathrm{cfu} / \mathrm{ml}\right.$ each). The total coliform count also showed that Randa has the highest coliform count of $20 \times 10^{5} \mathrm{cfu} / \mathrm{ml}$ followed by Ijaiye $\left(19.5 \times 10^{5} \mathrm{cfu} / \mathrm{ml}\right)$. Well water from Ita - Eko had the least value of $25 \times 10^{5} \mathrm{cfu} / \mathrm{ml}$ for the total plate count while Randa well had the highest $(90$ $\mathrm{x} 10^{5} \mathrm{cfu} / \mathrm{ml}$ ). The isolate identified were ; Escharichia coli, Pseudomonas species, Bacillus subtilis, klebsiella species and Enterobacter species. These wells are highly contaminated, this may be due to the fact that different users use different drawers to fetch the water, illegal dumping of domestic wastes, livestock rearing and closeness of septic tanks. This observation is similar to that Richmann(1997), he reported that the presence of coliforms group in water bodies may be due to contamination with Human or animal feces.

All the water samples showed high concentration of Escharichia coli, this pathogens may pose a special heath risk for infants,young children and people with severely compromised immune systems ${ }^{14}$. .The total plate count was also very high in comparism with NAFDAC standards (maximum level permited ,table 4). The percentage occurrence of Escharichia coli was $100 \%$ while the least was $27 \%$ for Pseudomonas sp (table5) This result indicates poor sanitary handling of the wells and the public health implication of this is obvious because feacal coliforms are associated with feacal matter, which may contain pathogens ${ }^{[21,22]}$. The water can only be used for public consumption if only the coliform count is zero, a count of one or more is taken as positive indication of feacal pollution and the possible risk of diseases ${ }^{23}$.

The results observed indicate that most well waters in Abeokuta metropolis are highly polluted and therefore unfit for human consumption without proper treatment.

\section{TABLE 1: PHYSICAL PARAMETERS OF WELL WATER SAIPLES COLLECTED FROMI DIFFERENT LOCATIONS}

\begin{tabular}{|c|c|c|c|c|c|c|c|c|}
\hline SN & LOCATION & TEMP $\left({ }^{\circ} \mathrm{C}\right)$ & COLOUR $(\mathrm{Hu})$ & ODOUR & TURBDITY & $\begin{array}{l}\text { TOTAL SOLD } \\
\text { (mgL) }\end{array}$ & $\begin{array}{l}\text { TOTAL } \\
\text { DISSOLVED SOLD } \\
\text { (mgL) }\end{array}$ & $\begin{array}{l}\text { TOTAL } \\
\text { SUSPENDED } \\
\text { SOLD (mgL' }\end{array}$ \\
\hline 1 & Panseke & 27.50 & 10 & $\begin{array}{l}\text { Unobjectiona } \\
\text { ble }\end{array}$ & $2.71 \pm$ & 385.70 & 223.00 & 162.70 \\
\hline 2 & Adigbe & 27.60 & 10 & " & $6.78+$ & 260.00 & 166.60 & 93.40 \\
\hline 3 & Oluwo & 27.60 & 5 & $"$ & $2.15+$ & 690.00 & 299.00 & 391.00 \\
\hline 4 & Kuforiij & 27.40 & 10 & Objectionable & $1.39+$ & 180.00 & 122.50 & 57.50 \\
\hline 5 & Ojere & 27.50 & 5 & " & $1.16 \pm$ & 450.00 & 287.00 & 163.00 \\
\hline 6 & Kuto & 27.60 & 5 & $"$ & $2.55+$ & 687.50 & 527.00 & 160.50 \\
\hline 7 & Ijaiye & 27.60 & 5 & $"$ & $2.49 \pm$ & 512.50 & 371.00 & 141.50 \\
\hline 8 & Olorunsogo & 27.50 & 5 & $"$ & $2.22 \pm$ & 512.50 & 396.00 & 116.50 \\
\hline 9 & Ita eko & 27.50 & 5 & $"$ & 2.22 & 614.30 & 332.00 & 282.30 \\
\hline 10 & Randa & 27.50 & 10 & $"$ & 2.67 & 903.30 & 614.00 & 289.30 \\
\hline 11 & Iberekodo & 27.50 & 5 & $\begin{array}{l}\text { Unobjectiona } \\
\text { ble }\end{array}$ & 2.73 & 746.70 & 574.00 & 172.70 \\
\hline 12 & Lafenwa & 27.10 & 10 & " & 3.72 & 718.50 & 657.00 & 61.50 \\
\hline 13 & Obantoko & 27.10 & 10 & $"$ & 1.05 & 112.50 & 31.60 & 80.90 \\
\hline 14 & Elewe Eran & 27.10 & 10 & $"$ & 3.80 & 325.00 & 150.20 & 174.80 \\
\hline 15 & Camp & 27.10 & 10 & $"$ & 2.13 & 214.30 & 92.00 & 122.30 \\
\hline
\end{tabular}


Physicochemical And Bacteriological Analyses Of Well Water In Abeokuta Metropolis, Ogun-State,

TABLE 2: CHEMICAL PARAMETERS OF WELL WATER SAMPLES FROM DIFFERENT LOCATIONS

\begin{tabular}{|c|c|c|c|c|c|c|c|c|c|c|c|c|}
\hline SN & LOCATION & $\begin{array}{l}\text { CONDUCTIVI } \\
\text { TY }(\mu \mathrm{S}(\mathrm{cm})\end{array}$ & $\begin{array}{l}\text { ACDIT } \\
Y \\
(\mathrm{mgl})\end{array}$ & $\begin{array}{l}\text { ALKALIN } \\
\text { TY (mgL) }\end{array}$ & $\begin{array}{l}\text { TOTAL } \\
\text { HARDNE } \\
\text { SS (mgl) }\end{array}$ & $\begin{array}{l}\text { SULPHA } \\
\text { IE (mgL) }\end{array}$ & $\begin{array}{l}\text { NIRAT } \\
\mathrm{E} \text { (mg } \mathrm{I})\end{array}$ & $\begin{array}{l}\text { NIRT } \\
\mathrm{E} \text { (mgL) }\end{array}$ & $\begin{array}{l}\text { CHLORI } \\
\text { DE (mgL) }\end{array}$ & $\begin{array}{l}\mathbb{I R O N} \\
\text { (mgL) }\end{array}$ & $\begin{array}{l}\text { CHLORIN } \\
\text { E } \\
\text { RESIDUA } \\
\text { L (mgL) }\end{array}$ & $\mathrm{pH}$ at $2 \mathrm{O}^{\circ} \mathrm{C}$ \\
\hline 1 & Panseke & 486 & 0.40 & $\mathrm{NL}$ & 69 & 1815.60 & 268.67 & 0.21 & 90 & NL & $\mathrm{NIL}$ & 6.64 \\
\hline 2 & Adigbe & 364 & 0.70 & NL & 40 & 1911.05 & 218.50 & 0.02 & 106 & NI & NI & 6.20 \\
\hline 3 & Oivio & 510 & 1.00 & NL & 93 & 191092 & 412.00 & 0.06 & 270 & NL & NI & 5.19 \\
\hline 4 & Kuforiji & 269 & 0.40 & NL & 39 & 1817.70 & 373.60 & 0.03 & 44 & NL & NL & 6.53 \\
\hline 5 & Ojere & 623 & 0.40 & NL & 67 & 1913.16 & 36.01 & 0.01 & 90 & NL & NIL & 6.60 \\
\hline 6 & Kuto & 1128 & 0.30 & NIL & 127 & 191201 & 44.10 & 0.02 & 271 & NL & NL & 691 \\
\hline 7 & lairye & 800 & 0.10 & NL & 80 & 1912.50 & 258.60 & 0.03 & 176 & NL & NIL & 7.40 \\
\hline 8 & Olonunsoge & 853 & 0.10 & NIL & 63 & 1912.66 & 363.63 & 0.02 & 132 & NL & NL & 7.47 \\
\hline 9 & It eko & 718 & 0.30 & NIL & 92 & 1911.41 & 269.40 & 0.02 & 112 & NL & NL & 6.89 \\
\hline 10 & Randa & 1306 & 0.20 & NI & 123 & 1913.01 & 209.40 & 0.02 & 298 & NIL & $\mathrm{NL}$ & 7.01 \\
\hline 11 & Iberckodo & 1223 & 0.30 & NI & 137 & 191212 & 410.14 & 0.05 & 264 & NL & NIL & 690 \\
\hline 12 & Lafenva & 1467 & 0.20 & $\mathrm{NL}$ & 82 & 1819.70 & 311.12 & 0.08 & 210 & NL & NL & 7.15 \\
\hline 13 & Obantoko & 73.1 & 0.90 & NL & 11 & 1911.20 & 15.09 & 0.02 & 34 & NL & NI & 5.79 \\
\hline 14 & Elene Eran & 335 & 0.40 & $\mathrm{NL}$ & 43 & 1913.65 & 37.79 & 0.02 & 83 & NL & $\mathrm{NI}$ & 6.68 \\
\hline 15 & Camp & 205 & 0.50 & NIL & 17 & 191277 & 57.59 & 0.02 & 53 & NIL & NIL & 6.04 \\
\hline
\end{tabular}

TABLE 3: MEAN VALUES OF METAL CONTENTS OF THE SAMPLES (mg /L)

\begin{tabular}{llllllllll}
\hline $\mathrm{S} / \mathrm{N}$ & $\mathrm{Mg}$ & $\mathrm{Na}$ & $\mathrm{K}$ & $\mathrm{Fe}$ & $\mathrm{Cu}$ & $\mathrm{Cr}$ & $\mathrm{Mn}$ & $\mathrm{Pb}$ & $\mathrm{Ca}$ \\
\hline 1 & 16 & 102.56 & 11.13 & 18.60 & 0.06 & $\mathrm{BDL}$ & 0.75 & 0.14 & 53 \\
2 & 3 & 48.30 & 7.66 & 16.12 & 0.02 & $\mathrm{BDL}$ & 0.53 & 0.12 & 37 \\
3 & 47 & 12.31 & 1.24 & 19.07 & 0.04 & $\mathrm{BDL}$ & 0.28 & 0.12 & 46 \\
4 & 2 & 78.60 & 13.21 & 18.90 & 0.03 & $\mathrm{BDL}$ & 0.59 & 0.15 & 37 \\
5 & 13 & 72.00 & 41.30 & 20.01 & 0.02 & $\mathrm{BDL}$ & 0.55 & 0.15 & 54 \\
6 & 31 & 6.04 & 1.54 & 19.37 & 0.04 & $\mathrm{BDL}$ & 0.23 & 0.17 & 96 \\
7 & 10 & 31.94 & 2.16 & 18.15 & 0.06 & $\mathrm{BDL}$ & 0.29 & 0.15 & 70 \\
8 & 41 & 98.24 & 12.14 & 17.54 & 0.03 & $\mathrm{BDL}$ & 0.50 & 0.14 & 22 \\
9 & 14 & 174.34 & 39.14 & 19.71 & 0.04 & $\mathrm{BDL}$ & 0.57 & 0.11 & 78 \\
10 & 48 & 88.28 & 13.46 & 18.90 & 0.08 & $\mathrm{BDL}$ & 0.55 & 0.12 & 74 \\
11 & 68 & 78.01 & 28.14 & 18.92 & 0.04 & $\mathrm{BDL}$ & 0.59 & 0.17 & 69 \\
12 & 33 & 104.12 & 9.11 & 19.80 & 0.02 & $\mathrm{BDL}$ & 0.49 & 0.19 & 49 \\
13 & 6 & 39.16 & 11.74 & 18.29 & 0.03 & BDL & 0.50 & 0.17 & 5 \\
14 & 6 & 190.12 & 32.16 & 17.80 & 0.05 & BDL & 0.51 & 0.20 & 37 \\
15 & 5 & 11.34 & 10.09 & 19.34 & 0.06 & BDL & 0.42 & 0.18 & 12
\end{tabular}

BDL=Below Detection Limit 
TABLE 4: BACTERIOLOGICAL ANALYSIS OF WATER

\begin{tabular}{|c|c|c|c|c|c|c|c|c|c|c|}
\hline \multirow[t]{2}{*}{$\mathbf{S} / \mathbf{N}$} & \multirow[t]{2}{*}{$\begin{array}{l}\text { Sample } \\
\text { Location }\end{array}$} & \multicolumn{2}{|c|}{$\begin{array}{l}\text { Presumptive } \\
\text { Coliform } \\
\text { Count } \\
(\text { x10 cfu/ml) }\end{array}$} & \multicolumn{2}{|c|}{$\begin{array}{lr}\text { Total } & \text { Coliform } \\
\text { count } & (\mathbf{x 1 0} \\
\text { cfu/ml }) & \end{array}$} & \multicolumn{2}{|c|}{$\begin{array}{lr}\begin{array}{l}\text { Confirm } \\
\text { count } \\
\text { cfu/ml })\end{array} & \begin{array}{r}\text { E.coli } \\
(\mathbf{x 1 0}\end{array}\end{array}$} & \multicolumn{2}{|c|}{$\begin{array}{lr}\text { Total } & \text { Plate } \\
\text { count } & (\times 10 \\
\text { cfu } / \mathrm{ml}) & \end{array}$} & \multirow[t]{2}{*}{$\begin{array}{l}\text { Organis } \\
\mathrm{m}\end{array}$} \\
\hline & & $\begin{array}{l}\text { Tes } \\
t\end{array}$ & $\begin{array}{l}\text { Max } \\
\text { Permitte } \\
\text { d level } \\
\text { (NAFD } \\
\text { AC) }\end{array}$ & Test & $\begin{array}{l}\text { Max } \\
\text { Permitte } \\
\text { d level } \\
\text { (NAFD } \\
\text { AC) }\end{array}$ & Test & $\begin{array}{l}\text { Max } \\
\text { Permitte } \\
\text { d level } \\
\text { (NAFD } \\
\text { AC) }\end{array}$ & Test & $\begin{array}{l}\text { Max } \\
\text { Permitte } \\
\text { d level } \\
\text { (NAFD } \\
\text { AC) }\end{array}$ & \\
\hline 1 & Panseke & 20 & 10 & 10.0 & 10 & 10 & 0 & 40 & 10 & $\begin{array}{l}\text { Escheric } \\
\text { hia coli, } \\
\text { Pseudom } \\
\text { onas sp, } \\
\text { Enteroba } \\
\text { cter sp. }\end{array}$ \\
\hline 2 & Adigbe & 35 & 10 & 17.0 & 10 & 10 & 0 & 40 & 10 & $\begin{array}{l}\text { Escheric } \\
\text { hia coli, } \\
\text { Klebsiell } \\
\text { a sp. }\end{array}$ \\
\hline 3 & Oluwo & 40 & 10 & 15.0 & 10 & 15 & 0 & 55 & 10 & $\begin{array}{l}\text { Escheric } \\
\text { hia coli, } \\
\text { Enteroba } \\
\text { cter sp. }\end{array}$ \\
\hline 4 & Kuforiji & 35 & 10 & 12.0 & 10 & 10 & 0 & 50 & 10 & $\begin{array}{l}\text { Escheric } \\
\text { hia coli, } \\
\text { Enteroba } \\
\text { cter sp. }\end{array}$ \\
\hline 5 & Ojere & 40 & 10 & 18.0 & 10 & 10 & 0 & 60 & 10 & $\begin{array}{l}\text { Escheric } \\
\text { hia coli, } \\
\text { Pseudom } \\
\text { onas sp., } \\
\text { Klebsiell } \\
\text { a sp. } \\
\end{array}$ \\
\hline 6 & Kuto & 25 & 10 & 10.0 & 10 & 10 & 0 & 30 & 10 & $\begin{array}{l}\text { Escheric } \\
\text { hia coli, } \\
\text { Klebsiell } \\
\text { a sp. }\end{array}$ \\
\hline 7 & Ijaiye & 40 & 10 & 19.5 & 10 & 10 & 0 & 60 & 10 & $\begin{array}{l}\text { Escheric } \\
\text { hia coli } \\
\text { Pseudom } \\
\text { onas sp., } \\
\text { Bacillus } \\
\text { subtilis } \\
\end{array}$ \\
\hline 8 & $\begin{array}{l}\text { Olorunso } \\
\text { go }\end{array}$ & 40 & 10 & 15.0 & 10 & 20 & 0 & 70 & 10 & $\begin{array}{l}\text { Escheric } \\
\text { hia coli, } \\
\text { Bacillus } \\
\text { subtilis, } \\
\text { Enteroba } \\
\text { cter sp. } \\
\end{array}$ \\
\hline 9 & Ita eko & 10 & 10 & 10.0 & 10 & 5 & 0 & 25 & 10 & $\begin{array}{l}\text { Escheric } \\
\text { hia coli, } \\
\text { Klebsiell } \\
\text { a sp. } \\
\text { Bacillus } \\
\text { subtilis } \\
\end{array}$ \\
\hline 10 & Randa & 60 & 10 & 20.0 & 10 & 20 & 0 & 90 & 10 & Escheric \\
\hline
\end{tabular}


Physicochemical And Bacteriological Analyses Of Well Water In Abeokuta Metropolis, Ogun-State,

\begin{tabular}{|c|c|c|c|c|c|c|c|c|c|c|}
\hline & & & & & & & & & & $\begin{array}{l}\text { hia coli, } \\
\text { Enteroba } \\
\text { cter sp. }\end{array}$ \\
\hline 11 & $\begin{array}{l}\text { Iberekod } \\
\text { o }\end{array}$ & 35 & 10 & 15.0 & 10 & 5 & 0 & 55 & 10 & $\begin{array}{l}\text { Escheric } \\
\text { hia coli, } \\
\text { Bacillus } \\
\text { subtilis, } \\
\text { Klebsiell } \\
\text { a sp. }\end{array}$ \\
\hline 12 & Lafenwa & 35 & 10 & 16.0 & 10 & 10 & 0 & 45 & 10 & $\begin{array}{l}\text { Escheric } \\
\text { hia coli, } \\
\text { Pseudom } \\
\text { onas sp., } \\
\text { Bacillus } \\
\text { subtilis }\end{array}$ \\
\hline 13 & $\begin{array}{l}\text { Obantok } \\
\text { o }\end{array}$ & 40 & 10 & 19.0 & 10 & 15 & 0 & 50 & 10 & $\begin{array}{l}\text { Escheric } \\
\text { hia coli, } \\
\text { Enteroba } \\
\text { cter sp. }\end{array}$ \\
\hline 14 & $\begin{array}{l}\text { Elewe } \\
\text { Eran }\end{array}$ & 40 & 10 & 15.0 & 10 & 12 & 0 & 64 & 10 & $\begin{array}{l}\text { Escheric } \\
\text { hia coli, } \\
\text { Enteroba } \\
\text { cter sp., } \\
\text { Klebsiell } \\
\text { a sp. }\end{array}$ \\
\hline 15 & Camp & 40 & 10 & 17.5 & 10 & 10 & 0 & 65 & 10 & $\begin{array}{l}\text { Escheric } \\
\text { hia coli, } \\
\text { Bacillus } \\
\text { subtilis, } \\
\text { Klebsiell } \\
\text { a sp. }\end{array}$ \\
\hline
\end{tabular}

TABLE 5: TYPES OF BACTERIA IDENTIFIED IN THE WATER SAMPLES.

\section{LOCATIONS}

$\begin{array}{ll} & \text { E.coli } \\ \text { Panseke } & + \\ \text { Adigbe } & + \\ \text { Oluwo } & + \\ \text { Kuforiji } & + \\ \text { Ojere } & + \\ \text { Kuto } & + \\ \text { Ijaiye } & + \\ \text { Olorunsogo } & + \\ \text { Ita eko } & + \\ \text { Randa } & + \\ \text { Iberekodo } & + \\ \text { Lafenwa } & + \\ \text { Obantoko } & + \\ \text { Elewe Eran } & + \\ \text { Camp } & + \\ \% & 100\end{array}$

\section{ORGANISMS}

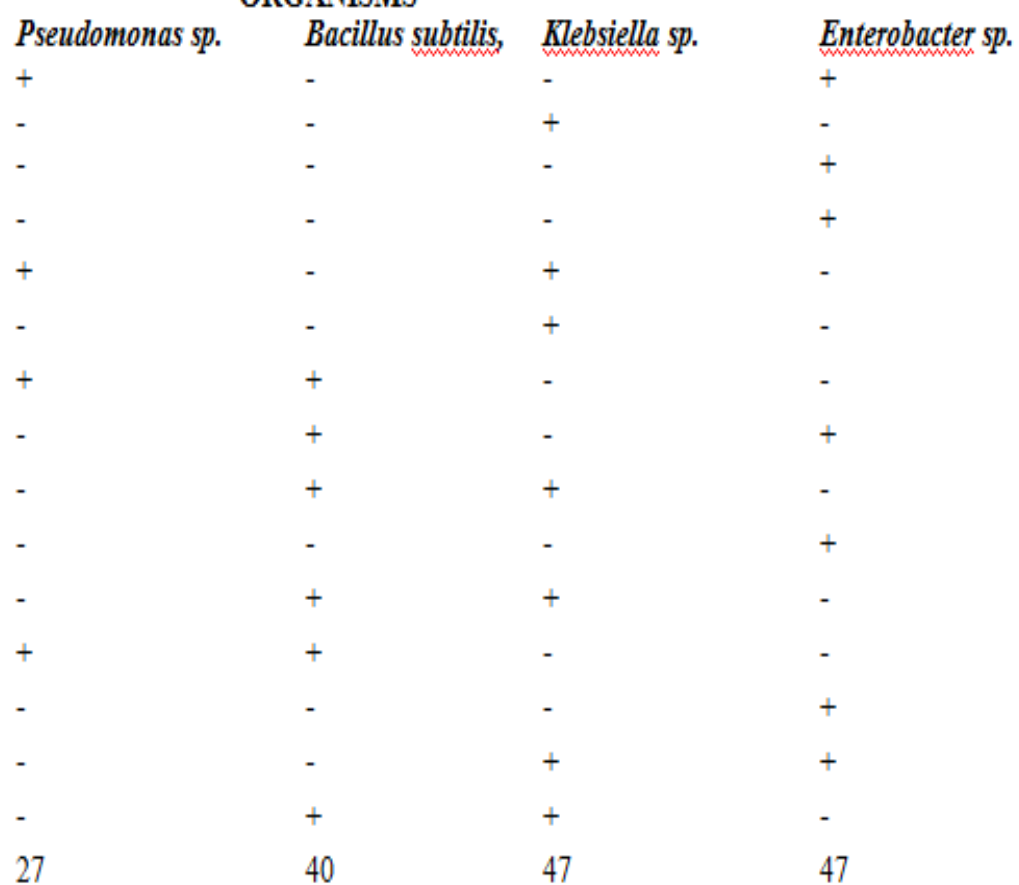




\section{References}

[1] Ipinmoroti K.O Water quality of shallow wells located close to dump sites in Akure, Nigeria. Pak.J.of Science and Ind. Res. 36(4), (1993) 137-142

[2] Twas, safe drinking water the need, the problem,solutions andaction plan. $3^{\text {rd }}$ world Academic of sciences, Italy, (2002). 8-12

[3] Mather, I.R Water resources distribution and uses (John wiley and $3^{\text {rd }}$ edition 1984). 265-268

[4] Ademoroti C.M.A, Standard methods for water and effluents analysis. Foludex press Limited, Ibadan. (1996). 79-171

[5] Trivedi, P.R and Raj. G Water pollution encyclopedia of environmental sciences Akashdeep publishing house. India (1997) .Vol 25, 139-162

[6] Association of official Analytical chemists, Water and salt official method of Analysis.14 ${ }^{\text {th }}$ edition Virgina (1984).USA

[7] America Public Health Association Standard methods for the examination of water and waste water, Washington D.C. (1985).144170,875-1012.

[8] Arora,D.R and Arora,B Bacteriological of water, Milikland air. in textbh of microbiology C.B.S publisher new - Delhi, $3^{\text {rd }}$ edition, (2008).739-740

[9] Baker,F.J and Breach,M.R(eds) Bacteriological examination of water,milk, food,air and ice-cream; In medical microbiological techniques Bulterwirth and co (publisher)Ltd,London, first edition, (1980).436 - 439

[10] Amoo .I A and A.M Akinbode Physico-chemical analysis of wel waters in Minna andit's environ, Niger state. Nigeria.J. Chemical society of Nigeria vol 32 (2), (2007).122-127

[11] Goel R.K Water pollution; causes, effects and control $2^{\text {nd }}$ Edition Maccmillan Publishers, London. (2006).154-232

[12] Nwosu ,J.N and Ogueke, C.C: Evaluation of satchet water in samples in Owerri metropolis. Nigerian Food Journal. (22), (2004) $164-170$

[13] Daniel, E.U; Alemede,I.C and Ibrahim,B.A: Bacteriological examination of some packaged water produced in Minna metropolis. In proceedings of the $31^{\text {st }}$ annual conference/General meeting of the Nigerian Institute of Food Science and Technology (Ed) Elemo G.N. (2007) 8-9,

[14] EPA, National primary drinking water standards: EPA drinking water quality standards website (2002).

[15] World Health Organization Guidelines for drinking water quality, Geneva World Organization (2003).

[16] SON Standard organization of Nigeria safe drinking water regulation (2003)

[17] Onuh, J.O and Isaac, V.U: Physico - chemical and microbiological quality of water sources from some major towns in Igala 27 (2), (2009)66-72

[18] Amao- Kehinde, O. A ;Agwunobi,G .O ; Adeyoju ,O.a ; Kayode O.F ; Etoamaihe ,M.A and Solomon, Hm. Composition and production of water sanitizers. Nigerian Food Journal (22), (2004) 40-42

[19] World Health Organisation: Guidelines for the examination of drinking water (2), 5-6, (1984) 17-39

[20] World Health Organisation Guidelines for drinking water quality,(5), (1999). $10-15$

[21] Rees,W Economic development and environmental protection An ecological economics perspective. Environment monitoring and Assessment.86, (2003).29-45

[22] Morinigo,M.A; Munoz,M.A; Cornax,R; Martinez - Manzanares,E; and Borrego, J.J, Presence of indicators and Salmonella in natural waters affected by outfall waste water discharges. Water Science and Technology. 25 : (1992). 1-8

[23] World Health Organization, Guidelines for drinking water quality, 2nd Edition Health critatia and other supporting information. Geneva (1996). 